\title{
RELIGIOSIDAD MESOAMERICANA Y CRISTIANISMO EN EL SIGLO XVI
}

LENGUAJES VISUALES, LÍRICA GUERRERA Y LITURGIA

\author{
MESOAMERICAN RELIGIOUSNESS AND \\ CHRISTIANITY IN THE XVITh CENTURY \\ VISUAL LANGUAGES, WAR SONGS AND LITURGY
}

Pablo Escalante Gonzalbo

UNAM

pabloeg@unam.mx

\begin{abstract}
This work refers to the persistence of various components of the Mesoamerican liturgy and their integration into the Christian liturgy. Various indigenous ornaments, warrior shields and flower and feather arrangements became part of the colonial ceremonies. Even the new liturgical objects, such as crosses, banners, and candles, were made with indigenous materials and techniques. The article delves into the iconographic analysis of one of these pieces, a chalice cover made with the feather mosaic technique with the appearance of a small shield. And finally, the survival of pre-Hispanic military songs and symbols in the New Spanish liturgy is addressed.
\end{abstract}

Keywords: liturgy, syncretism, feather art, evangelization, militarism.

\section{Resumen}

Este trabajo se refiere a la persistencia de varios componentes de la liturgia mesoamericana y a su integración en la liturgia cristiana. Diversos ornamentos indígenas, escudos guerreros y arreglos a base de flores y plumas pasaron a formar parte de las ceremonias novohispanas. Incluso los nuevos objetos litúrgicos, como cruces, estandartes y ciriales, se elaboraron con materiales y técnicas indígenas. El artículo profundiza en el análisis iconográfico de una de estas piezas, un cubrecáliz de plumaria con apariencia de pequeño escudo. Y finalmente se aborda la supervivencia de cantos y símbolos militares prehispánicos en la liturgia novohispana.

Palabras clave: liturgia, sincretismo, plumaria, evangelización, militarismo. 


\section{Introducción}

En este artículo examino evidencias de una adaptación muy temprana de elementos de la tradición religiosa indígena a la liturgia cristiana, tales como danzas, desfiles y escenografías; flores, plumas (en especial de quetzal) y escudos. Reviso algunos ejemplos y dedico especial atención al análisis de un cubrecáliz de plumaria con apariencia de pequeño escudo: lo identifico propiamente como una palia, y argumento sobre su significado cristiano en el contexto de la lectura tipológica de los sacramentos. Concluyo subrayando la importancia de la ideología guerrera que impregna los cantos indígenas antes y después de la conquista, y la paradoja de que se suprimieran las guerras indígenas, pero persistiera la ideología guerrera en aspectos importantes de la nueva liturgia.

El trabajo forma parte de los estudios sobre el arte cristiano-indígena de la Nueva España, y en especial de aquellos que estudian la liturgia como ámbito de intercambio cultural y sincretismo (Estrada de Gerlero, 2011; Escalante Gonzalbo, 2005). Las fuentes utilizadas en este caso son crónicas, cantares y otros testimonios escritos del siglo XVI, así como pictografías y algunos objetos conservados hasta nuestros días; entre ellos, el célebre cubrecáliz.

Entre los bailes de sus antiguas fiestas, los preferidos por los indios, según fray Diego Durán, eran aquellos en los cuales llevaban abundantes flores. El dominico destaca la celebración dedicada a Xochiquétzal que se hacía frente al templo de Huitzilopochtli. Se levantaba una rica escenografía con árboles artificiales repletos de flores; también se cubrían de flores los altares y los cuerpos de los danzantes. Muchachos disfrazados de pájaros y mariposas, vestidos con plumas "verdes y azules y coloradas y amarillas" se subían a los árboles y "andaban de rama en rama chupando el rocío de aquellas rosas" (Durán, 1967: I, 193).

Esas ricas escenografías en las que se simulaban bosques, así como la profusión de flores en todas las ceremonias y los feste- jos religiosos, llamaron mucho la atención de los frailes y en general consideraron que no entraban en conflicto con las prácticas cristianas. Por el contrario, veían con agrado que las fiestas y devociones cristianas se acompañaran con todos esos componentes de vistosidad desbordada, característicos de la fiesta indígena.

\section{El paraíso florido y la liturgia indígena}

Entre 1536 y 1539, fray Toribio de Benavente o Motolinia atestiguó con entusiasmo y dejó constancia de la participación masiva de las comunidades indígenas en las procesiones de Corpus, en las fiestas patronales, en la de Domingo de Ramos y otras más, en particular en la zona de Tlaxcala. Todas las celebraciones descritas por Motolinia muestran gran semejanza con las fiestas prehispánicas en varios aspectos, que a simple vista podríamos llamar escenográficos y, hasta cierto punto, coreográficos. Se fabricaban bosques artificiales, los participantes se disfrazaban -muchos de ellos con plumas- y había flores en abundancia: en arcos y parapetos, en tapetes y en las manos de la gente (Motolinia, 1971: 90-105). Para la procesión de Corpus de 1538, por ejemplo, se mencionan diez arcos triunfales grandes, mil sesenta y ocho medianos y otros sesenta y seis pequeños, "todos cubiertos de rosas y flores de diversas colores", de manera que tenía cada arco hasta una carga y media de rosas (Motolinia, 1971: 99).' En total, entre los arcos y lo que la gente llevaba o iba arrojando por el camino, el fraile calculó dos mil cargas de flores. Con cierta satisfacción, detalla también que "la quinta parte parecía ser de clavelinas, que vinieron de Castilla" (Motolinia, 1971: 100).

Dejando a un lado las expresiones directamente sacrificiales, los rasgos más característicos de la fiesta religiosa mesoamericana, y nahua en particular, eran, por una parte, la importancia de la música, la danza y la teatralidad, y por la otra la presencia de disfraces, plumas, flores y animales, sobre todo pájaros.

1 Es decir, cerca de 150 kilos de flores cada arco. 
La fiesta del miércoles de la octava de Pascua de Resurrección que presenció Motolinia en Tlaxcala en 1539 (Motolinia, 1971: 104-105) es un ejemplo espectacular de la supervivencia indígena, y lo es también de la aprobación que los religiosos podían sentir frente a todo ese aparato festivo volcado a la liturgia cristiana. Tras la procesión y la entrega de limosnas, el momento central de la fiesta era una representación del auto de "la caída de nuestros primeros padres". El esmero en la recreación del Paraíso nos recuerda las instalaciones de bosques y jardines de las fiestas prehispánicas, como la de Xochiquétzal a la que se refería Durán. Es muy probable que el propio Motolinia haya contribuido a la planeación de este auto o ejemplo, pues la otra noticia que tenemos de una representación muy temprana del mismo tema es precisamente de Cuernavaca (Horacasitas, 1974: 175), donde Motolinia fue guardián, antes de ir a Tlaxcala.

Recrearon, junto al hospital del convento, una colina boscosa con peñas y ríos, poblada de animales. El dispositivo parece ir mucho más allá de lo que hubiera requerido el drama del pecado de Adán tal como se representaba en Europa desde el siglo XII (Horcasitas, 1974: 175). Siguiendo la técnica tradicional de los montajes festivos de los nahuas, se combinaron árboles y flores reales con otros fabricados, y también había una combinación de animales reales con otros que no eran sino hombres disfrazados de animales. Además de flores y frutas, las copas de los árboles estaban repletas de aves de todos tipos: pájaros pequeños, búhos y otras aves de rapiña "y sobre todo muy muchos papagayos, y era tanto el parlar y gritar que tenían, que a veces estorbaban la representación" (Motolinia, 1971: 105). En un solo árbol, Motolinia contó catorce de ellos. Tenemos que suponer que se trataba por igual de loros y guacamayas, y esta estampa nos deja ver que, a veinte años de iniciada la conquista, seguían activas las prácticas de comercio y cría de estas especies en localidades en las que no eran endémicas. También había una gran cantidad de conejos y liebres, y al menos dos gatos monteses muy inquietos, amarrados, uno de los cuales se escapó sin consecuencias. En un peñasco dentro del bosque artificial había un muchacho disfrazado de "león" que desgarraba y devoraba un venado, "el venado era verdadero". En cierta forma, esta muerte del venado en la representación puede verse como un acto sacrificial, justificado aquí por la evocación del mundo natural, primitivo que se hacía enfáticamente en la obra.

Un componente muy típicamente indígena visible en esta celebración era el jugueteo: Ios muchachos que estaban disfrazados de animales hacían burlas y toqueteos entre sí y con Adán y Eva. De hecho, la propia escena del pecado parece haber ido precedida de un insistente ir y venir de Eva, tres o cuatro veces, entre la serpiente y Adán, con escarceos melindrosos hasta que consiguió la aceptación de Adán (Motolinia, 1971: 105). Esta combinación de lo jocoso y lo solemne, lo trágico y lo burlesco, es propia de las fiestas mesoamericanas.

\section{Ornamentos indígenas y liturgia}

También en los ornamentos elaborados para las fiestas se pone de manifiesto la supervivencia de la tradición mesoamericana, tanto en los motivos como en las técnicas decorativas. Destacan la elaboración de figuras de animales y los disfraces de plumaria, así como la combinación de orfebrería con labores de plumaria, utilizada para custodias, cruces y ciriales; también, para adornar las andas y para las mangas que cubrían las varas de las imágenes y las cruces procesionales. En algunos casos se advierte que las plumas eran "de precio, que llamaban quetzalli” (Motolinia, 1971: 96).

En los estudios sobre el arte novohispano, no se ha prestado suficiente atención a este primer grupo de obras de arte litúrgico indígena que formó parte de las procesiones y fiestas cristianas y se movió entre las calles, los atrios y las capillas. Debido a la fragilidad de las plumas y al reciclaje del oro con el paso del tiempo, casi no hemos conservado objetos de este brillante repertorio. 
Contamos, desde luego, con las descripciones: "traen cruces pequeñas de a palmo o palmo y medio o dos palmos, cubiertas de oro y pluma”, dice Motolinia (1971: 95-96). Pero también hay algunos códices coloniales en los cuales se representaron estas obras. Uno de los casos más tempranos es el del Códice de Huejotzingo (1531), donde aparece gran cantidad de objetos, mantas y piezas de oro tributados por los indígenas a las rapaces autoridades de la Primera Audiencia. Entre los estandartes hay varios de plumas de quetzal y un cuadro de la Virgen, de mosaico de plumaria. En cuanto a las piezas de orfebrería, contamos con las imágenes de 1540, del catálogo de joyas de Martín Océlotl (Noguez, 2016), si bien en este caso no se trata de objetos litúrgicos sino de la riqueza personal del mago nahua perseguido por la inquisición.

En el Códice florentino se documenta bien, en texto e imagen, la continuidad de las técnicas muchas décadas después de la conquista: podemos apreciar la combinación de plumaria y orfebrería en un escudo (Sahagún, 1979: IX, 52 v.); la elaboración de ornamentos de oro de estilo europeo, como flores y alas de ángeles (Sahagún, 1979: IX, 53 r.), y algunos estandartes de plumaria (Sahagún, 1979: IX, 62 v.-63 r.). Sin embargo, es en el Códice de Tepetlaóztoc donde percibimos la mayor semejanza con los objetos litúrgicos descritos por Motolinia. Si bien el códice fue elaborado en 1554, incluye inventarios muy completos de los tributos entregados a Hernán Cortés, a Miguel Díaz y, principalmente, a Gonzalo de Salazar, factor de la Real Hacienda, que tuvo la encomienda de aquel pueblo de la región de Tetzcoco muchos años.

El códice es testimonio de atropellos inauditos debido a los montos exigidos, tanto de alimentos como de mantas y oro; debido también a la arbitrariedad con la que los encomenderos imponían e incrementaban esos montos y, finalmente, por la violencia con la que los mayordomos realizaban la recaudación, atemorizando al pueblo para condicionarlo a pagar más. ${ }^{2}$

2 Los abusos empezaron desde la época en que
Las cargas tributarias que pagaba el pueblo de Tepetlaóztoc se completaban con joyas, especialmente desde 1530, cuando Luis Vaca, mayordomo del encomendero Gonzalo de Salazar, apaleó a algunos principales. Tras la paliza, "de miedo le dieron una joya de oro, más de lo que eran obligados" (Códice de Tepetlaóztoc, 1994, fac.: 15 v.), se trataba de un chimalli o rodela de oro y plumaria, cuyas dimensiones no se especifican (Códice de Tepetlaóztoc, 1994, fac:: 16 r.).

Cuando Gonzalo de Salazar tuvo que emprender un viaje a España, en 1531, impuso a la gente de Tepetlaóztoc el pago de nuevos tributos y les obligó a trasladarlos a Veracruz, lo cual costó la vida a muchos de ellos.

Por el volumen y tipo de tributos, está claro que el factor no solamente quería sufragar sus gastos de viaje, sino además hacer negocio vendiendo en España algunas mercancías.

Sólo de esa forma se explica que entre los muchos tributos llevados para embarcar en Veracruz estuvieran 400 pares de alpargatas y 200 pares de sandalias.

Los indios, temerosos de las represalias de Salazar y su mayordomo, entregaron todo lo que se les pedía: guajolotes, gallinas, cacao, el calzado mencionado y además una serie de preciosos ornamentos, entre los que destacan estandartes, llamados penachos en algunos documentos, hechos a base de oro, con aplicaciones de piel y plumaria.

Es muy probable que fueran de uso procesional, como los descritos en las fuentes tempranas. Entre ellos destaca el estandarte de una cruz con el asta forrada de piel de jaguar y con una guarnición de plumas (figura 1). El fuste de la cruz tiene algunas flores y un mono de oro que enrosca su cola en el travesaño (Códice de Tepetlaóztoc, 1994, fac.: 19 v.).

\footnotetext{
Cortés tenía la encomienda. Esto fue entre 1523 y 1525 En este último año, el mayordomo de Cortés llegó a quemar vivos a cuatro principales del pueblo, porque no le entregaban los tributos en el plazo que se les había impuesto.
} 
Figura $1^{3}$

\section{Estandarte con una cruz, flores, un mono y otros adornos. Realizado en oro y plumaria con piel de jaguar}

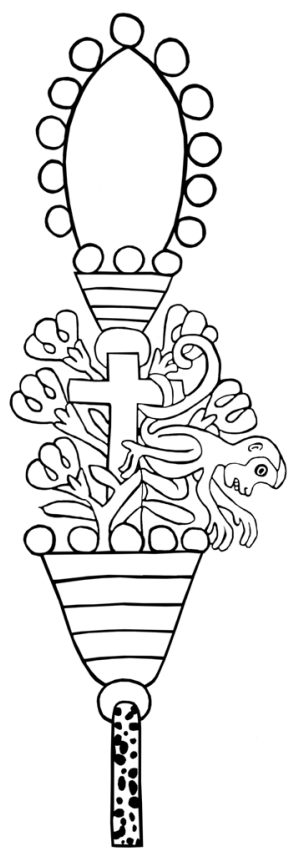

Fuente: Códice de Tepetlaóztoc (1994, fac.: 19 v.).

Luis Vaca y otro mayordomo de apellido Espinosa siguieron recolectando el tributo a nombre de Salazar y abusando de los indios periódicamente. En 1535, Vaca informó a las autoridades indígenas de Tepetlaóztoc que su patrón, el factor Salazar, lo había mandado llamar a España, y que necesitaría tributos extraordinarios para financiar su viaje. Entre otros muchos bienes, los indios se vieron obligados a entregarle sus joyas y estandartes. Uno de ellos es una cruz, similar a aquella que describe Motolinia, de oro y plumas, con cascabeles colgando de la base y el travesaño (Códice de Tepetlaóztoc, 1994, fac.: 25 r.) (figura 2).

La continuidad del trabajo artesanal indígena se explica en buena medida porque era compatible y fue integrado a la nueva vida litúrgica.

3 Todas las figuras son propiedad del autor y fueron dibujadas por Pamela Zubillaga.
Figura 2

Cruz de oro con decoración de plumaria y cascabeles

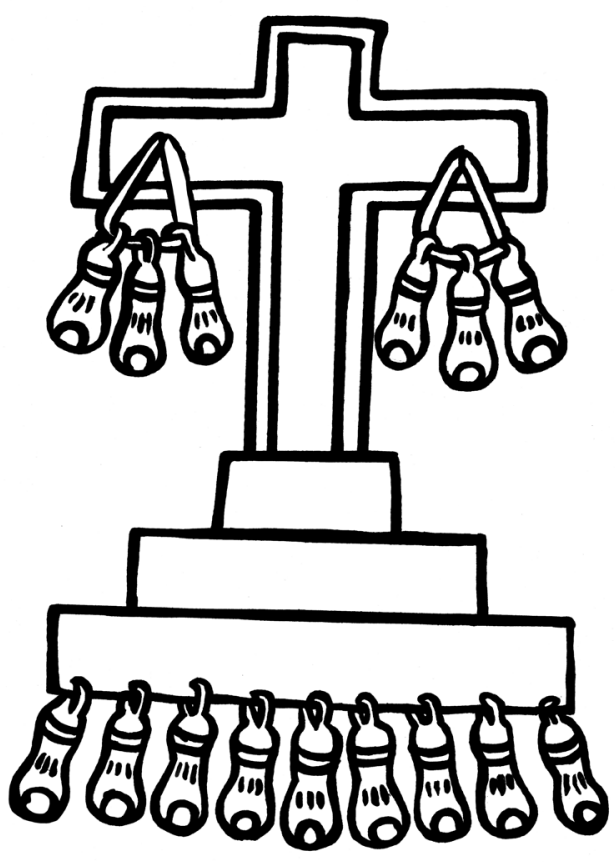

Fuente: Códice de Tepetlaóztoc (1994, fac.: 25 r.).

Además, las escuelas de artes y oficios de los conventos contribuyeron a la preservación de formas, técnicas y materiales. Por otra parte, y al menos desde 1533, la investigación formal que los frailes realizaron sobre la cultura indígena les permitió conocer el lenguaje pictográfico y los principales símbolos de la antigua cultura. Debido a ese conocimiento pudieron acordar con los indígenas los términos idóneos para la inclusión de una parte del repertorio prehispánico en las nuevas imágenes y en el ornamento de los nuevos espacios.

Es una triste paradoja que el logro alcanzado por los artesanos indígenas y los frailes, visible en imágenes como la cruz del mono o la cruz de oro y plumaria, y cuyo destino era la fiesta cristiana indígena, haya terminado, en algunas ocasiones, convertido en mercancía o fundido para saciar las demandas de los encomenderos. 


\section{La palia, una pictografía de la salvación}

Los pocos objetos litúrgicos indígenas tempranos que se conservan corresponden con piezas que, a diferencia de los estandartes, andas o penachos, podían guardarse en una sacristía, preservarse dentro de muebles e incluso bajo llave. Tal es el caso de la cruz de altar hoy conservada en la catedral de Palencia. El fuste y el travesaño son de cristal de roca; la imagen de Cristo y la base son de plata. El Gólgota representado en la base está surcado por ríos de diseño pictográfico indígena, con cuentas de jade y caracoles, y poblado de animales a la manera de las escenografías festivas a las que nos hemos referido; entre ellos, mariposas, felinos, reptiles y serpientes emplumadas (García Barrios y Parada López de Corselas, 2014).

Otra pieza ceremonial de enorme valor es el llamado cubrecáliz de plumaria del Museo Nacional de Antropología de la Ciudad de México (figura 3). Se trata de una pieza circular, de 28 centímetros de diámetro, formada por varias capas de fibra vegetal prensada y diseños elaborados con la técnica del mosaico plumario. ${ }^{4}$ Se asemeja a primera vista a las rodelas mexicas, pero es claramente distinta por su menor tamaño y por la ausencia de la estructura de cañas, el asa y los flecos de pluma que caracterizan a los escudos.

Figura 3

\section{Palia o cubrecáliz de plumaria}

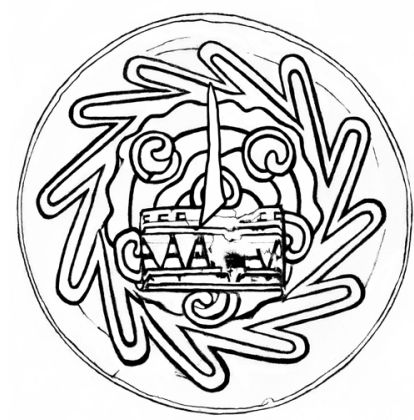

Fuente: Museo Nacional de Antropología e Historia.

4 Existe un detallado estudio de los materiales y las técnicas (Filloy Nadal, Solís Olguín y Navarijo Ornelas, 2007).
El disco fue dado a conocer en 1939 por Rafael García Granados, quien creía que podía tratarse de una pieza de origen prehispánico, que había formado parte de un chimalli; es decir, sería el recorte de la zona central del escudo. En sus breves notas, García Granados expresa un prejuicio que fue muy extendido hasta que empezamos a reconocer que las formas y motivos del arte indígena habían prevalecido en el siglo XVI con pleno conocimiento y participación de los propios frailes, y como parte de una liturgia sincrética. El prejuicio consistía en sospechar que la pieza, por ser de aspecto indígena, tenía que haber sido escondida en su contexto colonial. Por otra parte, al describir el presunto escondite, García Granados dejó las claves para comprender qué cosa era el disco y qué función tenía.

Este disco de plumaria se encontró escondido bajo el forro de la tapa de la caja de un cáliz del siglo XVI, utilizado por los frailes franciscanos en lo que hoy es el estado de Hidalgo. La caja, que está hecha de paja y forrada con tela de algodón y piel de venado, se utilizaba para cargar el cáliz de una iglesia o capilla a la otra (García Granados, 1939: 3).

Trasladar el cáliz de un lugar a otro fue, a lo largo de la historia, y es aún, una práctica común; con más razón en el siglo XVI novohispano, cuando desde una cabecera debían administrarse los sacramentos a más de una docena de iglesias de visita. Para trasladar el cáliz se utilizaba un estuche ${ }^{5}$ (figura 4), operación que aún se practica. En el estuche, junto al cáliz, van los complementos necesarios para oficiar: el purificador, la patena, la palia y el corporal $^{6}$ (figura 5). De hecho, cuando el ministro se encuentra en un lugar en el que no existe un altar,

5 Se conservan todavía algunos estuches antiguos forrados de piel en algunas parroquias. Un caso español: <https://bit.ly/2ZyQsBu>, consultado el 28 de noviembre de 2020.

6 El purificador es un paño para limpiar el cáliz, la patena y los dedos del sacerdote. La patena es un pequeño plato sobre el que se coloca la hostia. La palia es un trozo de tela, normalmente cuadrado, rígido, que se usa para tapar el cáliz durante la misa. El corporal es un pequeño lienzo de tela blanca que se desdobla para colocar sobre él el cáliz y la patena. 
puede oficiar sobre una mesa sencilla, en la cual debe colocar el corporal para impedir que el cáliz entre en contacto con una superficie no consagrada (Martimort, 1987: 232).

\section{Figura 4}

Antiguo estuche de cáliz español, realizado en cuero. Procedencia desconocida

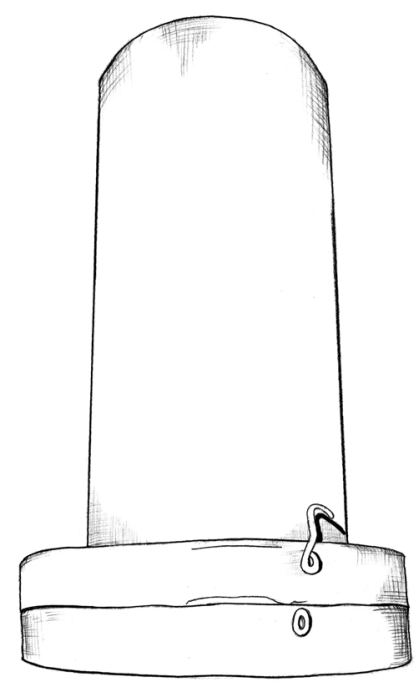

Figura 5 El cáliz, la hostia y los complementos litúrgicos

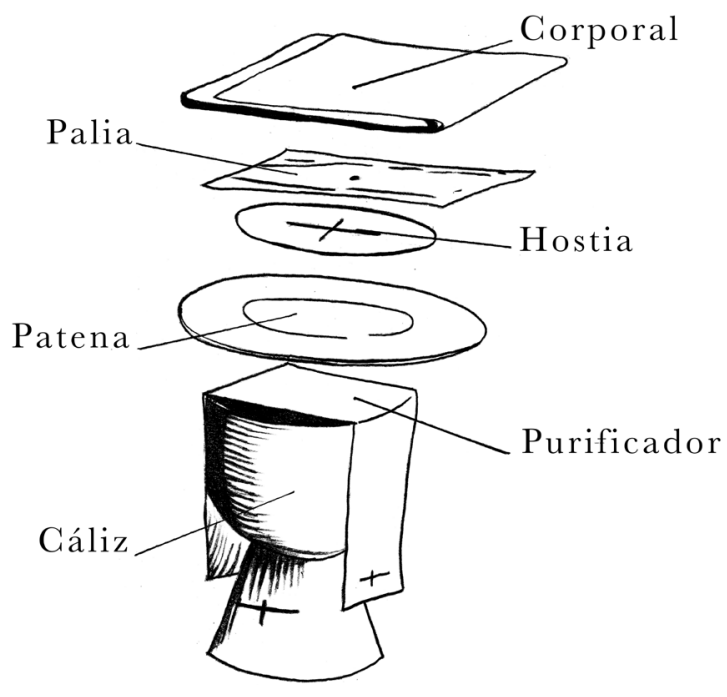

En la Edad Media sólo existía el corporal y en el Renacimiento se agregó el uso de la palia, una piececita cuadrada o circular, de tela rígida o almidonada, que se coloca entre la patena y el corporal al iniciar la misa. Antes de la consagración, cuando el corporal ya está extendido en el altar, y sobre él se han puesto el cáliz y la patena, la palia se usa para tapar el cáliz; se entiende que lo cubre y lo protege. La pieza que encontró García Granados guardada en el estuche del cáliz corresponde con toda seguridad con la palia. Su peso y grosor hace muy poco probable que hubiese estado pegado o cosido al centro de un corporal, y precisamente corresponde con el requisito de la palia, que debe tener la rigidez que no ofrece una pura tela. Por su forma circular y su rica ornamentación, correspondería con el tipo de palia que los manuales de liturgia llaman "hijuela" (Liturgia papal). Si, como se ha dicho -aunque García Granados no publicó ese dato-, este coleccionista le retiró al disco dos trozos de tela de los costados (Estrada de Gerlero, comunicación personal, 2005), puede haber sido un tipo de palia, común también, que era cuadrado, pero con el círculo decorado o hijuela sobrepuesto.

El hecho de que la palia se haya encontrado dentro del estuche o porta cáliz es absolutamente normal. Ése era su lugar. Sobra decir que esconder el objeto en el estuche que un fraile iba a abrir y cerrar constantemente carece de sentido.

En 1970, Ferdinand Anders mencionó el disco en un listado de obras indígenas de plumaria, y planteó una reserva a la suposición de que se tratara de un escudo o de parte de un escudo, al catalogarla literalmente así: "Rodela (mejor dicho, disco) de pluma. Museo Nacional de Antropología" (Anders, 1970: 33). Sin embargo, no profundizó más en su denominación del disco.

Sobre la iconografía de la pieza, García Granados creía que el conjunto representaba un jeroglífico toponímico, compuesto por el remolino de agua, una franja de tierra cultivada (el elemento horizontal) y una púa de maguey (el elemento vertical de color amarillo) (García Granados, 1939: 3). 
Hasta donde tengo noticia, nadie ha puesto en duda la identificación del agua y la tierra. Ambos elementos de la identificación original de García Granados han prevalecido.

En una breve mención de 1983, Nicholson y Quiñones identificaron la figura amarilla vertical del centro como un palo plantador, y dejaron abierta la posibilidad del significado toponímico (Nicholson y Quiñones Keber, 1983: 151). En mi propio análisis de 2005 (Escalante Gonzalbo, 2005 y 2012), encontré los tres elementos principales: agua, tierra y huictli o palo plantador, pero propuse una ruta de interpretación distinta a la de la toponimia, en el contexto de la iconografía sacramental. En 2006, Alfonso Lacadena sugirió una lectura silábica en lengua náhuatl de los mismos elementos (Lacadena, 2006).

El único trabajo extenso dedicado exclusivamente al disco de plumaria se ocupa de sus aspectos materiales, mismos que ha esclarecido enormemente Filloy Nadal et al. (2007). Estos autores analizaron a detalle la técnica de elaboración e identificaron las aves con las que corresponde la totalidad de las plumas utilizadas en el mosaico. Es interesante señalar que los autores de este trabajo observaron una continuidad suficiente con la tecnología prehispánica como para dejar abierta la posibilidad de que se tratara de una pieza prehispánica, e incluso, como lo había sugerido García Granados, que fuese parte de un escudo recortado (Filloy Nadal et al., 2007: 88). Reconocen, sin embargo, como un rasgo peculiar de esta pieza, el uso de cera en lugar de otros adhesivos más frecuentes en la tecnología antigua (Filloy Nadal et al., 2007: 92-93).

En 2014 apareció una nueva mención al disco en un trabajo de Alessandra Russo (2014: 33-36). Su interpretación coincide con las versiones anteriores al señalar el remolino de agua y la franja de tierra, pero difiere en el asunto del huictli, que considera un rayo de fuego. Tal sugerencia es difícil de aceptar: el artista que elaboró el disco conocía bien los estereotipos pictográficos mesoamericanos y los aplicó para el remolino y la tierra (también para las "fauces" de la tierra, como veremos). ¿Por qué no usó el pictograma de fuego? El estereotipo era bien conocido en el siglo XVI y lo emplearon otros artistas indígenas de la época, como los pintores de la iglesia de Tecamachalco, Puebla (Escalante Gonzalbo, 2006: 337-339). Tampoco se valió el artista de la palia de las convenciones pictográficas para rayos solares o descargas eléctricas. En realidad, el elemento central del disco no corresponde con otro pictograma de la tradición mesoamericana que no sea el del huictli, como lo observaron originalmente Nicholson y Quiñones.

En fin, Ana García Barrios ha tenido el cuidado de hacer un recuento de varias publicaciones en las que se hace referencia al disco, y en especial recuperó los argumentos inéditos de Lacadena a los que agregó un énfasis en la importancia del color amarillo del fondo del disco, al cual se había prestado menos atención.

Expongo aquí mi interpretación del disco como un objeto sacramental, para su discusión.

\section{La pictografía. Lo que vemos}

El disco de plumaria ostenta motivos de la tradición indígena, ya lo hemos visto. La totalidad de las formas que apreciamos en la pieza tienen correspondencia con el lenguaje pictográfico de los códices mesoamericanos. Por ello es lógico que, desde la primera publicación en 1939, hasta el estudio más completo sobre la materialidad de la pieza, de 2007, se haya considerado la posibilidad de que fuera de origen prehispánico. En términos generales, las plumas, la técnica del mosaico, y también las figuras empleadas en la composición, son de tradición mesoamericana.

El brillante fondo amarillo coincide con tonalidades que vemos en otros objetos de plumaria, como los escudos del Códice mendocino, y especialmente en las rodelas de greca o xicalcoliuhqui de Stuttgart (Torres, 2020).

La forma dominante en la composición, que es la masa de agua en movimiento, está 
dibujada con las gruesas líneas negras típicas del lenguaje pictográfico (Escalante Gonzalbo, 2010: 48). Las crestas sucesivas, propias del chorro de agua que se bifurca o salpica, son parte del pictograma mesoamericano, del mismo modo que lo son los pequeños remolinos interiores. Un caso similar de agua que brota y se pone en movimiento se utilizó para ilustrar la fundación de México Tenochtitlan en el Manuscrito To$\operatorname{var}$ (fol. 91 v.) (figura 6).

Figura 6

El nopal sobre el agua en la fundación de México Tenochtitlan

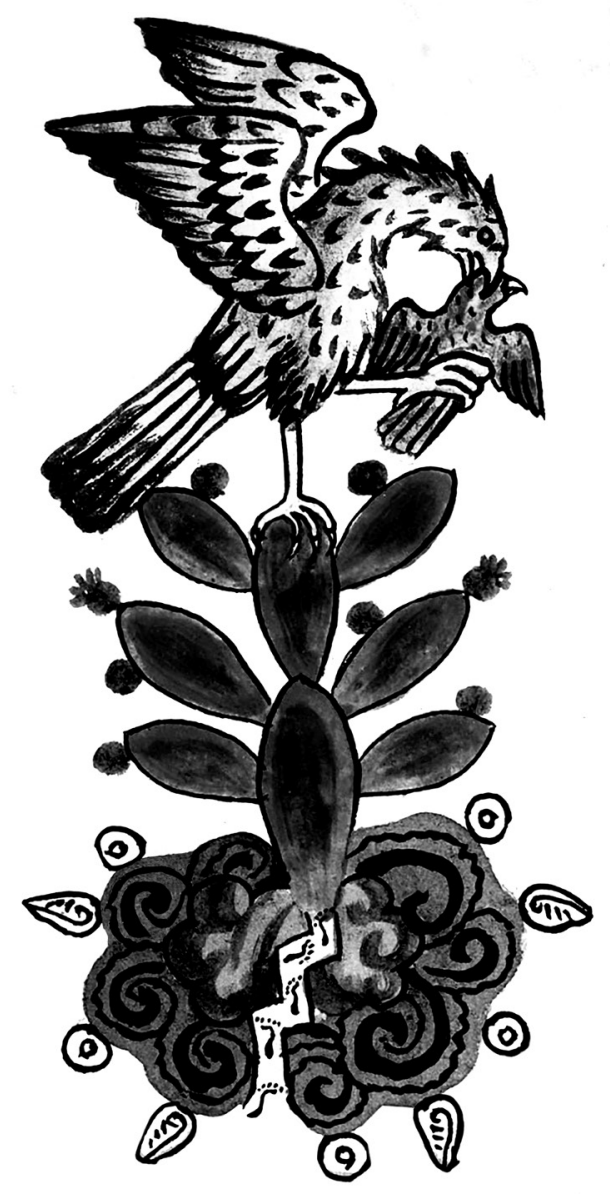

Fuente: Manuscrito Tovar (fol. 91 v.).

Las representaciones pictográficas del suelo solían hacerse con franjas horizontales, a las que se les colocaban unos dentículos recostados (con la parte abierta hacia un lado) dispuestos en sucesión. Muchos pictogramas toponímicos utilizaron el recurso (figura 7), lo cual explica, hasta cierto punto, que García Granados haya imaginado que la figura representaba un topónimo. El color blanco podría corresponder con un suelo calizo o rocoso. Y en cuanto a los picos, corresponden con el diseño de los colmillos de cipactli, el lagarto de la tierra (Códice Borgia, lám. 27) (figura 8). La división de cada triángulo en dos partes coincide, en las imágenes mitológicas, con la encía y el diente; en la imagen del disco la división también fue marcada, pero no el color. Leer esto como la abertura de una roca parece bastante viable.

Figura 7 Pictograma de Acamilixtlahuacan
en el Códice mendocino

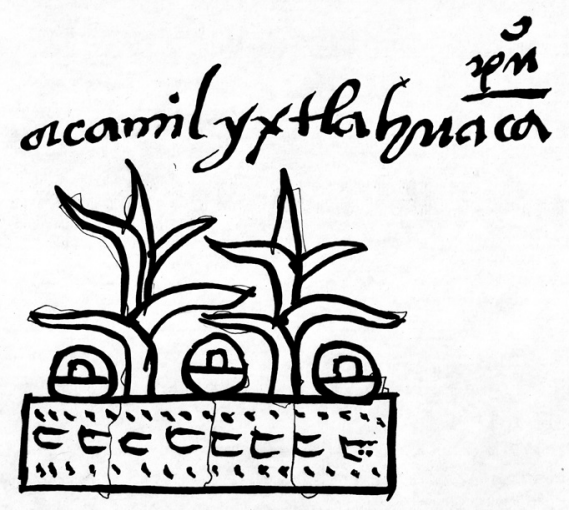

Fuente: Códice mendocino (36 r.).

Figura 8 Cipactli o lagarto

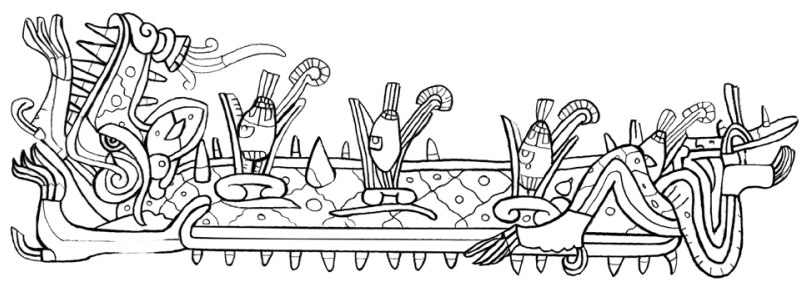

Fuente: Códice Borgia (lám. 27).

La pieza amarilla central tiene la forma característica del huictli, el instrumento de cultivo mesoamericano por excelencia, e 
incluso la tonalidad amarilla coincidiría con algunas de las imágenes que en los códices hacen referencia a la madera del instrumento. En la glosa en español, en el caso del Códice mendocino (fol. 70 r.) (figura 9), se la identifica como coa, que era el nombre taíno para un instrumento similar y los españoles habían aprendido en las Antillas.

\section{Figura 9}

Joven que recibe asignación de trabajo. Frente a él, un huacal y un huictli o coa

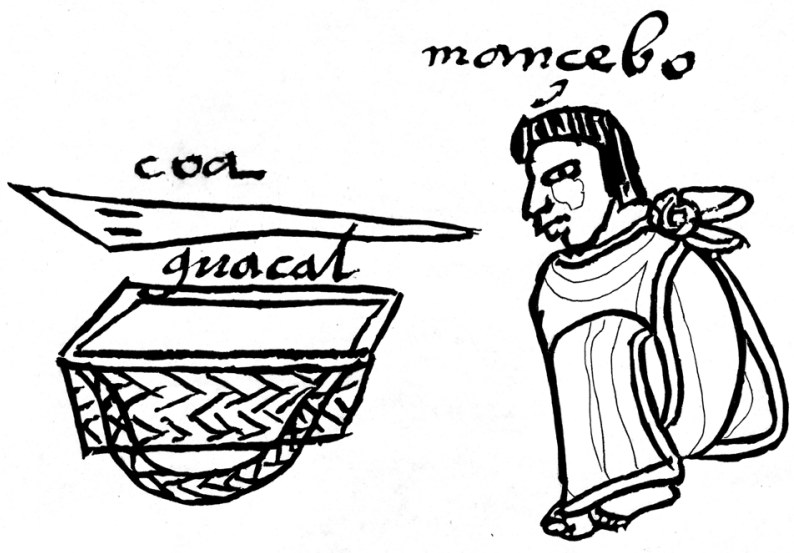

Fuente: Códice mendocino (fol. 70 r.)

Es muy interesante observar algunas imágenes del Códice florentino que muestran el huictli en relación con la tierra: una de ellas, ya de concepción muy naturalista, presenta justamente la función del huictli en relación con la cavadura y la conducción del agua (Sahagún, 1979, vol. III, fol. 228 r.) (figura 10).

En otra escena, cuyas formas y composición son más tradicionales indígenas, vemos el huictli suspendido sobre la tierra (Sahagún, 1979, vol. III, fol. 227 v.) (figura 11).

Esto es muy importante, se trata de un recurso típico de la composición pictográfica: la asociación entre el pictograma huictli y el suelo es un tanto conceptual, implica la información de que se utiliza para surcar, golpear, incidir en la tierra.
Figura 10

Campesino que excava el suelo con su huictli para conducir el agua

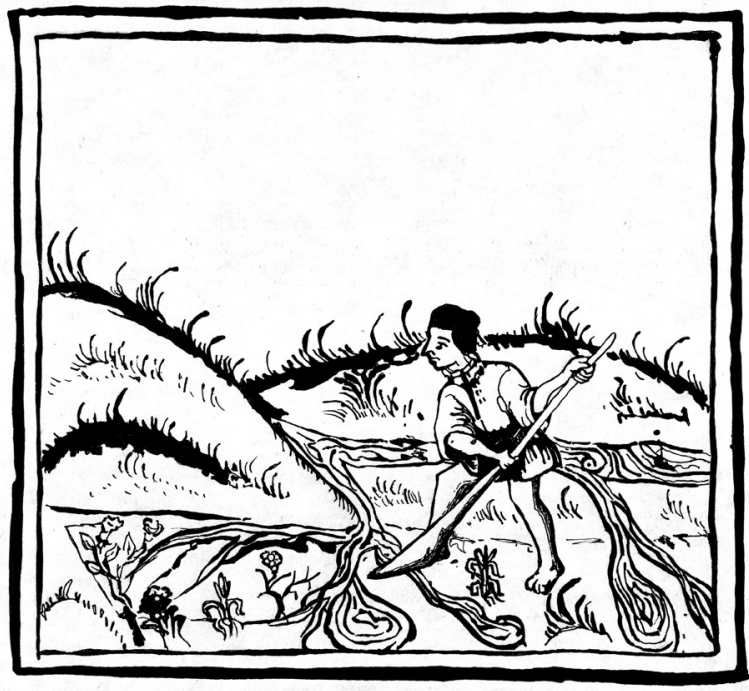

Fuente: Sahagún (1979, vol. III, fol. 228 r.).

Figura 11

Suelo arcilloso. El uso del huictli se indica con el instrumento suspendido sobre la tierra

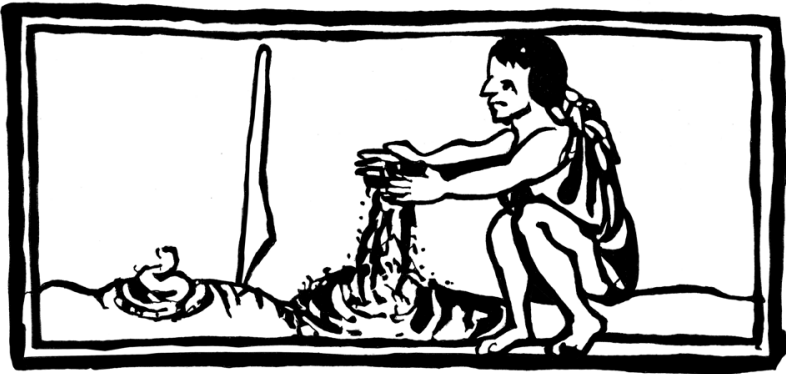

Fuente: Sahagún (1979, vol. III, fol. 227 v.)

Un instrumento de madera golpea la roca, que se abre y deja brotar agua en abundancia. Ésta es la lectura que me parece viable para la composición pictográfica que se realizó en el disco de plumaria. La cuestión que sigue, por supuesto, es explicar qué significa eso, y qué relación guarda con la función del objeto. 


\section{Sacramentum Christi}

La información sobre el contexto en el que se encontró esta pieza es fundamental. Nunca sabremos qué fue del estuche de piel, ni qué del cáliz, si es que se encontraba dentro del estuche. Lo que sí sabemos es que en el mismo estuche se guardaba la palia, y acaso antiguamente también el corporal.

El disco que nos ocupa era la palia o hijuela: un objeto de gran valor litúrgico. Estaba en contacto con la hostia y con el cáliz; de hecho, cubría a este último un instante antes de la consagración: se retira la palia, el sacerdote coloca sus manos sobre el cáliz y se produce la transubstanciación. Por lo tanto, cabe esperar que la iconografía de la palia cifre ese instante y esa función sacramental.

A. G. Martimort, uno de los más destacados liturgistas contemporáneos e historiador de la liturgia, explica lo siguiente: "Los signos utilizados por la liturgia son principalmente signos bíblicos. La inteligencia de los sacramentos viene dada por la evocación de los tipos bíblicos en la catequesis y en las grandes plegarias consagratorias" (Martimort, 1987: 163).

En especial, tomemos nota de esta observación: "La inteligencia de los sacramentos viene dada por la evocación de los tipos bíblicos [...]”. Así se entienden, así se explican los sacramentos, evocando los tipos bíblicos. Los tipos bíblicos son esos sucesos del Antiguo Testamento que se interpretan como prefiguras o "sombras" de las revelaciones del Nuevo Testamento.

La lectura tipológica de la Biblia se ha practicado desde la época de los primeros padres de la iglesia, está vigente aún, y se considera especialmente importante para explicar y justificar los sacramentos (Martínez M., s.f.).

Un ejemplo de esa lectura tipológica sería la interpretación del diluvio universal: purificación por el agua y salvación de Noé y su familia, como prefigura del bautismo.

Para los frailes que impulsaron la primera evangelización en Nueva España fue muy importante la explicación simbólica de la liturgia y la práctica de la tipología bíblica (Estrada de Gerlero, 2011: 63-65). A tal punto estaban convencidos los religiosos de la importancia de la lectura tipológica, que llegaron a aplicarla a la propia religión mesoamericana, como si se tratara de una tradición pre-cristiana más, con señales evangélicas y de Salvación.

Reflexionando sobre la lectura tipológica, Erasmo dice lo siguiente:

[...] diligentemente escudriñemos las figuras y misterios encerrados en las Santas Escrituras. Si no, dime, ¿̇qué cosa es en este propósito el agua escondida en las venas de la tierra, sino los misterios encubiertos con la letra? ¿Qué cosa es manar el agua de sus venas acá afuera, sino declararse los misterios y secretos maravillosos escondidos debajo della [...] que muy bien se podrán llamar ríos? (Erasmo, 1932: 132).

El Enquiridion encarnaba como ninguna obra de su tiempo el espíritu combativo, de milicia cristiana, muy apreciado por los franciscanos. Pocos autores fueron más influyentes en la ideología de los frailes reformados que vinieron a Nueva España.

Para la formulación de ejemplos y para un abordaje pedagógico de la Biblia, se utilizó mucho en la tardía Edad Media y en el Renacimiento un tipo de libro, del cual hay varias versiones, y que genéricamente ha sido llamado Biblia pauperum o Biblia de los pobres. Se le dice así por tratarse de una Biblia analfabeta, una Biblia en imágenes. Pero era mucho más que eso.

La singularidad de la Biblia pauperum estriba, precisamente, en que está organizada en forma tipológica. Se juntan en cada lámina escenas del Antiguo Testamento y su correspondiente en el Nuevo.

Digamos que se trataba de una guía para la lectura tipológica o para la identificación de las figuras bíblicas. Veamos la lámina que nos ayuda a esclarecer en definitiva el sentido eucarístico del disco de plumaria (figura 12). 
Figura 12

Pares tipológicos en la Biblia pauperum: Moisés golpea la roca y mana el agua. Un romano ha clavado la lanza en el costado de Jesús

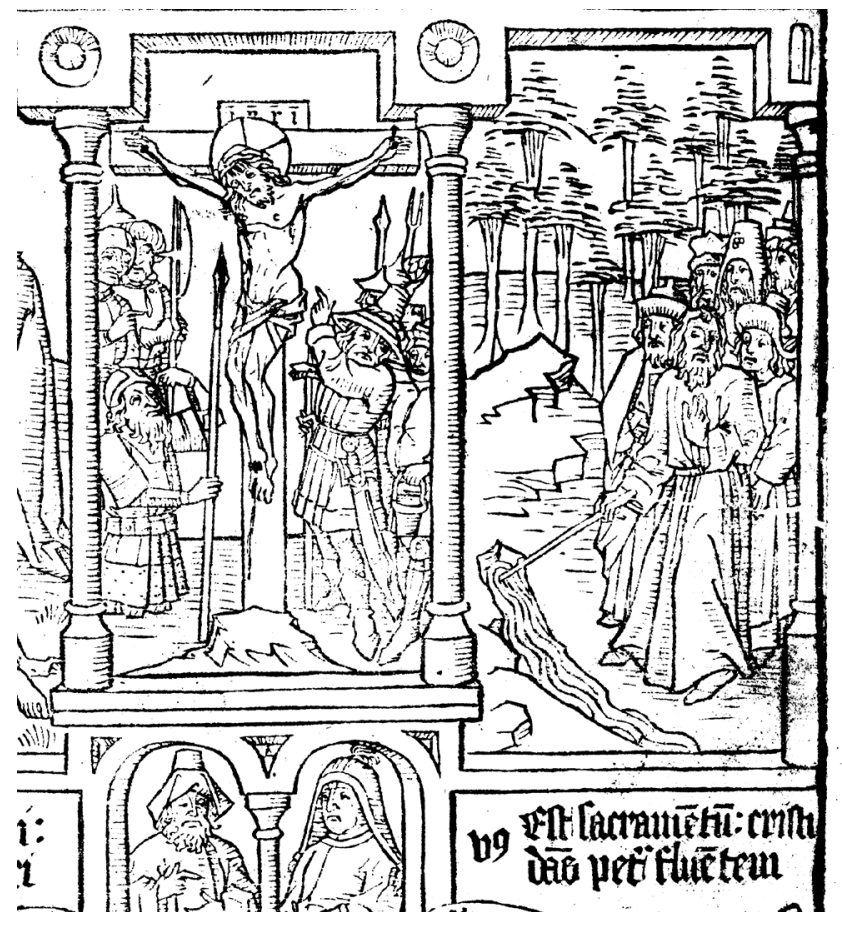

Fuente: Biblia pauperum (1987, Secuencia de la Pasión, lám. F).

Cada lámina está formada por una composición arquitectónica, como un pequeño retablo. La estructura cuenta con un banco, un ático y un cuerpo central dividido por dos columnas para formar tres vanos. A lo largo de todo el libro, el vano central está ocupado por escenas de la vida de Cristo hasta su muerte y resurrección, y termina con la coronación de la Virgen. De tal suerte, el centro de cada lámina es el Evangelio. $Y$ en los vanos de los lados se colocan escenas del Antiguo Testamento que se consideran figuras, también llamadas prefiguraciones o sombras, del hecho evangélico. A menudo se hacen observaciones tocantes a los sacramentos que se derivan, precisamente, de los episodios de la vida de Cristo. En la última lámina de la vida de Cristo, ${ }^{7}$ le vemos crucificado, y junto a él un romano con la lanza que apunta a su costado. En

7 Lámina F de la secuencia de la Pasión. el vano derecho de la composición aparece un pasaje del Antiguo Testamento en el que Moisés clava su bastón de madera en la roca y con ello hace que mane agua. El lema en latín, bajo la escena de Moisés, dice: "Est Sacramentum Christi dans petra fluentum [El agua que fluye de la piedra es el sacramento de Cristo]" (Biblia pauperum, 1987).

Un texto complementario, en la esquina superior de la lámina, explica [traduzco libremente]: "La roca o piedra significa Cristo, que vertió las aguas de la Salvación (es decir, los sacramentos) ${ }^{8}$ de su costado, cuando desde la cruz permitió que éste fuera perforado por la lanza de un soldado".

Ésta parece ser la razón para haber escogido el bastón de madera que golpea la piedra y hace fluir el agua como representación del sacramento en la palia que cubrió aquel cáliz de Tepeapulco, de Cempoala o cual haya sido esa doctrina franciscana de Hidalgo que García Granados prefirió no revelar.

Cuando profundizamos en el análisis de las imágenes litúrgicas realizadas por los indígenas en el siglo XVI, cuando exploramos las analogías y las traducciones realizadas en conjunto por los indígenas y los frailes, podemos apreciar que estaba en marcha un profundo proceso de asimilación de las dos tradiciones, y éste involucraba un conocimiento sólido de los textos bíblicos, de los fundamentos teológicos de la liturgia, de los textos de los padres de la Iglesia y de la obra de humanistas como Erasmo.

\section{La cuicacalli ${ }^{9}$ cristiana}

Ciertamente la palia no es un escudo, puesto que carece del diámetro, la estructura y los flecos. Y vaya que a lo largo del siglo XVI se hicieron muchas de estas rodelas, para danzas casi profanas como las de moros y

8 Literalmente, scilicet sacramenta.

9 Deliberadamente utilizo este término como guía de una indagación que debemos profundizar. El aprendizaje de cantos y baile era central en la educación nahua, estaba ligado a la religión y a la guerra. La continuidad del canto y la danza en la etapa novohispana no se desligó totalmente de algunos componentes ideológicos de la antigua práctica. 
cristianos o las de chichimecos y también para los bailes litúrgicos. Eran rodelas grandes que, bien empuñadas, se levantaban al aire durante la danza.

Muchos de los cantos que los indígenas utilizaban mientras bailaban al son de los tambores en los atrios de los conventos pertenecían a su antigua tradición, y los frailes estaban conscientes de ello. Al menos desde $1536^{10}$ y hasta $1570^{11}$ se registra como algo común que la participación indígena en las festividades religiosas va acompañada de música, baile, cantos y, por supuesto, las flores, plumas e insignias de que hemos hablado. Tales fechas corresponden con las narraciones de Motolinia y Durán, respectivamente; muy detallados, ambos, al describir el entorno litúrgico que presenciaban como parte de su rutina pastoral. Pero, en realidad, lo que Motolinia registra se había ido preparando en los años previos, como él mismo permite ver; y lo que observaba Durán en su libro sobre los ritos siguió practicándose muchos años después.

Las descripciones, las imágenes de varios manuscritos y las transcripciones de los cantos mismos ponen en evidencia también la continuidad de los instrumentos musicales tradicionales. ${ }^{12}$ Para la danza se usaban principalmente el huéhuetl o tambor de parche y el teponaztli, más agudo y melódico que el huéhuetl. Francisco Cervantes de Salazar describe algunos detalles de la danza indígena e indica que el teponaztli estaba en el centro, junto al tambor vertical, y los indios formando círculos alrededor. Lo describe como un "tamboril de palo, todo hueco, y

10 En la descripción de una celebración que tuvo lugar en 1536, dice Motolinia: “[...] y salen los indios señores y principales ataviados con sus camisas limpias y mantas blancas y labradas, con plumajes y piñas de rosas en las manos, bailan y dicen cantares en su lengua [...]" (Motolinia, 1971: 91).

11 Fecha en la que habría terminado de escribir su libro de los ritos y ceremonias. Ángel Ma. Garibay, en sus notas a la Historia de las Indias de Nueva España e Islas de Tierra Firme (Durán, 1967: p. xvii).

12 Atabales, "sus trompetas e unas flautillas no muy bien entonadas" y "unos huesezuelos que suenan mucho" (Motolinia, 1971: 384). Manuscrito Tovar (fols. 118 v y 119 r.). en el medio sacadas dos astillas, una par de otra, del mismo gordor del palo; en aquellas toca un indio diestro con dos palos que tienen el golpe guarnescido con nervios; suenan más de una legua" (Cervantes de Salazar, 1971: vol. I, 134). Hay un teponaztli de gran antigüedad en el Museo de Etnología de Viena ${ }^{13}$ (figura 13). La decoración en las franjas de ambos extremos guarda una semejanza muy interesante con motivos del Códice Magliabechi (Boone, 1983: 5 v.) y, en general, sus adornos plumarios y de flores corresponden con la iconografía cristiana indígena de mediados del siglo XVI. Una vez más, flores y plumas son los ornamentos centrales. También aparece la acción de libar.

Se trata de un tema importante de la iconografía religiosa mesoamericana, lo vemos en relación con cierta idea indígena del paraíso, asociada a su vez con la muerte de los guerreros. Los muchachos disfrazados de pájaros representaban una libación de flores en la fiesta de Xochiquétzal, mencionada antes (Durán, 1967: vol. I, 193). Y en diversos códices aparecen pájaros libando, como el propio Códice Magliabechi, donde un colibrí se acerca a libar de una flor que cuelga del tocado de Quetzalcóatl (Boone, 1983: fol. 49 r.). En el caso del teponaztli, se trata de mariposas provistas de plumas en la cola, que liban lo que parecen ser flores de hibiscus.

\section{Figura 13 Teponaztli, siglo XVI}

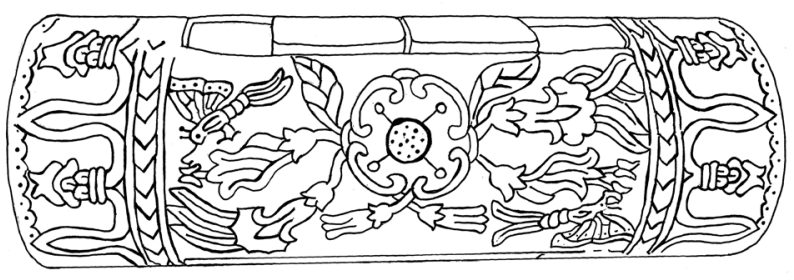

Fuente: Nowotny (1961).

13 Basamos nuestro dibujo en el de Nowotny (1961). Agradezco a Gerard Van-Bussel, del Weltmuseum de Viena, por su ayuda en la localización del teponaztli y sus dibujos. 


\section{Cantos de guerra}

Los cantos y danzas tradicionales de los indios eran guerreros. Éste es uno de los asuntos más interesantes en la historia de la evangelización y de la liturgia indígena del siglo XVI: se suprimieron las guerras de los señoríos y se prohibieron los sacrificios humanos, pero se conservaron danzas y cantos guerreros, también insignias y estandartes. Motolinia era optimista sobre la posibilidad de sustituir el contenido de los antiguos cantos con un contenido cristiano:

Bailan y dicen cantares en su lengua de las historias de las fiestas que celebran, que las han traducido los frailes en su lenguaje, y los maestros de sus cantares las han puesto a su modo en metro que cuadre y se cante al son de sus cantares antiguos [...] (Motolinia, 1971: 91).

Muchos años después, Durán sigue teniendo una opinión favorable al uso de los cantos indígenas en la liturgia. Él pensaba que era conveniente que los señores indígenas continuaran pagando y patrocinando a músicos que compusieran sus cantos, pues de ese modo se les permitía mantener una costumbre que les daba prestigio en sus comunidades y les permitía "no decaer en la autoridad de sus personas" (Durán, 1967: vol. I, 195). Sobre el contenido de los cantos que hacían estas "capillas" de cantores al servicio de los caciques, dice "no lo tengo por inconveniente, pues ya no se hace sino a buen fin" (Durán, 1967: vol. I, 195). Reconoce que las metáforas de estos cantos son muy "oscuras", que a él le cuesta entenderlas, pero que, después de platicarlo y examinarlo "son admirables sentencias, así en lo divino que agora componen, como en los cantares humanos que componen". Y concluye: "no hay que reprender en general" aunque "podría haber algún descuido" (Durán, 1967: vol. I, 196).

Durán reconoce, sin embargo, que en algunas danzas hay indígenas guiando el baile, que llevan atuendos semejantes a los de sus antiguos sacerdotes y que se ponen a entonar "sus idolatrías, cantos y lamentaciones", y cuando aparece algún religioso que sabe la lengua "mudan el canto y cantan el cantar que compusieron de san Francisco, con el Aleluya al cabo" (Durán, 1967: vol. I, 122). Ya a mediados del siglo XVI, Cervantes de Salazar comentaba el cambio que se había procurado, al permitir a los indios conservar las danzas siempre y cuando los cantos alabaran a Dios. Pero veía con preocupación que "si no hay quien entienda muy bien la lengua, entre las sacras oraciones que cantan mezclan cantares de su gentilidad" (Cervantes de Salazar, 1971: vol. I, 135).

La verdad debe estar en algún lugar entre el optimismo y la suspicacia. Y probablemente dependería mucho de qué comunidad se tratara, del tipo de autoridad de los caciques y de la calidad de su relación con los españoles, también de la fuerza de la presencia del convento en la vida de la comunidad. Lo cierto es que había una política de sincretismo (Escalante Gonzalbo, 2005), un proyecto que siempre incluyó la conservación de las prácticas indígenas y la sustitución de lo que se consideraba contrario a la nueva religión.

La Psalmodia Christiana de Sahagún es el mejor ejemplo del esfuerzo de los frailes por construir esa alternativa al canto indígena. Como se sabe, fue un proyecto de Sahagún y los escolares indígenas con quienes siempre trabajó. Así, a los cantos que ya venían componiendo en lenguas indígenas otros frailes desde la década del 1530, se sumó, hacia $1569,{ }^{14}$ la Psalmodia. La obra circuló intensamente por medio de copias manuscritas; fue aprobada tras el examen que encargó el arzobispo Moya de Contreras en 1578, y autorizada para su publicación en 1583 (García Icazbalceta, 1981: 322-323). El riguroso Tercer Concilio Provincial recomendó su uso en $1585 .^{15}$ La obra se aprovechó durante mucho tiempo. Todavía en el siglo XVIII había ejemplares en la biblioteca del convento de san Francisco de México, cuando un ardiente notario revisor de la inquisición mandó quemarlos (García Icazbalceta, 1981: 326).

14 Anderson en su prefacio (Psalmodia, 1993: p. x.). 15 Anderson en su introducción (Psalmodia, 1993: 16). 
En los hermosos cantos de la Psalmodia están presentes muchas de las metáforas y los tópicos propios de los antiguos cantares indígenas. Están las flores, las plumas, el jade, y está también la guerra. Esto, desde la perspectiva cristiana, era posible: ¿no se había llamado por siglos arma Christi a los instrumentos de la pasión, las armas con las que Cristo venció a la muerte y al diablo? Las metáforas guerreras también estaban en el Antiguo Testamento, en las cartas de San Pablo, en toda la tradición cristiana en realidad. Uno de los magníficos salmos nahuas dedicados a la resurrección habla de la gran guerra, la gran batalla que libró Jesús en la cruz contra nuestros enemigos. La muerte y el gran diablo fueron hechos prisioneros. Fueron derrotados, fueron superados por Jesús, que los hizo prisioneros (Psalmodia, 1993: 114). Es sólo un ejemplo.

El manuscrito que conocemos como Cantares mexicanos, y que con toda probabilidad fue reunido por los colaboradores de Sahagún ${ }^{16}$ para tener un modelo con el que construir la Psalmodia, reúne todas aquellas canciones que los indios entonaban en las danzas religiosas desde los inicios de la evangelización. Reflejan lo que dicen Motolinia, Cervantes de Salazar o Durán: son cantos antiguos, con metáforas y temas de la cultura indígena anterior a la conquista. Pero muchos de ellos tienen dedicatorias, loas, menciones al Dios único o al Espíritu Santo... Representan aún la antigua tradición, muchas de cuyas figuras eran alusivas al sacrificio humano y a la guerra, pero apuntan también hacia conceptos cristianos como el de la salvación. Parecen reflejar, en suma, ese esfuerzo temprano de los frailes por vaciar los cantos de contenido idolátrico; conservaban temas antiguos junto a sonoros aleluyas.

\section{Guerreros cristianos y escudos}

En algunos cantares es evidente el ejercicio de adaptación; hay estrofas de contenido histórico entreveradas con menciones

16 Estudio de León-Portilla en Cantares mexicanos (2011: v. I, 180-183). del Dios único, a veces nombrado en náhuatl, "Ipalnemohuani", a veces en español, "Dios". Así, por ejemplo, en un canto dedicado a Tezozomoc, y en una misma estrofa, se menciona a Ixtlilxóchitl, a Huitzilíhuitl, y se hace una referencia a la parusía: llegará Dios, disolverá los reinos, y esto hace llorar a Tezozomoc (Cantares mexicanos, 2011: v. II, tomo I, 95). Estrofas más adelante:

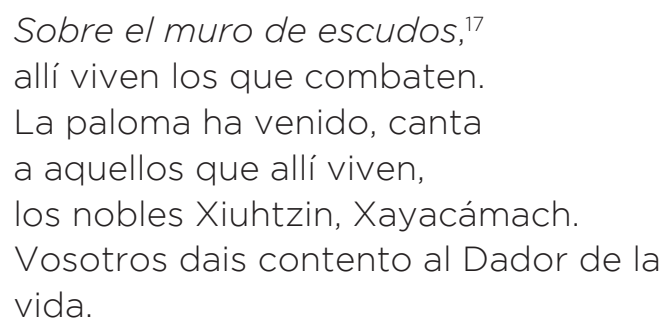

(Cantares mexicanos, 2011: v. II, tomo I, 101).

La llegada de la Paloma da continuidad al anuncio de la parusía hecho líneas arriba: "vendrá [...] él, Dios". El mensaje se asocia con la imagen guerrera del muro de escudos, y la mención de los que combaten. Los escudos vuelven a aparecer en otros cantares, junto a llamamientos metafóricos a la guerra, que terminan exaltando a Dios y la Salvación.

[...] en verdad lo digo, vosotros,

/ amigos nuestros,

quien suplica al Dios único, su corazón amorosamente le

/ entrega.

$[\ldots]$

En verdad se vive en

/ Quenonamican, 18

en el interior del cielo, sólo allí se es feliz.

Los cascabeles resuenan, el polvo se levanta como humo, es deleitado Dios, el Dador de la / vida. ${ }^{19}$

17 Las cursivas son mías

18 El lugar donde no se muere, el lugar donde no hay muerte, por lo tanto, donde se es inmortal.

19 "Dios Ypalnemohuani": así se expresa en el texto náhuatl, "Dios" en castellano, y el conocido giro que tiene el sentido de "Creador": aquel a quien debemos 
Los escudos, las flores, brotan, ${ }^{20}$

el miedo se extiende,

$[\ldots]$

hay aquí muerte florida [...]

(Cantares mexicanos, 2011: v. II, tomo I, 108-111).

Ya se aprecia el tipo de contradicciones que prevalecen en estos cantos intervenidos: se hace un llamamiento a los compañeros -a los otros guerreros-, se exalta la Salvación, al Dios único, pero a la vez se advierte de la proximidad de la muerte en la llanura, la guerra florida.

Las imágenes evocadas por los cantos, como el muro de escudos, o los escudos que brotan junto a las flores mientras suenan los cascabeles y se levanta el polvo, parecen corresponder con las danzas mismas que los cantores iban realizando.

Ya Motolinia se había referido a la presencia de los escudos en la gran procesión de Corpus celebrada en Tlaxcala en 1538: "hacen escudos grandes y chicos de labores de las mismas rosas" (Motolinia, 1971: 91). Y "Había obra de mil rodelas hechas de labores de rosas, repartidas por los arcos" (Motolinia, 1971: 100).

Motolinia dejó, además, una extensa descripción de las danzas indígenas que le tocó presenciar en su tiempo, llena de admiración por la "gran destreza" y por el "primor y gentileza" que observaba. Habla de las multitudes que participaban en ellas, de corros gigantescos de danzantes que se iban relevando a lo largo de las horas, para descansar; menciona antorchas encendidas y cantos tan fuertes que "óyese gran trecho, en especial a do el aire lleva la voz". "En estos bailes sacan muchas divisas y señales en que se conocen los que han sido valientes hombres de guerra" (Motolinia, 1971: 385).

A mediados de siglo, Cervantes de Salazar realiza también una descripción detallada de las danzas que los indios conservaban, y precisa: "Ilevan el brazo derecho

la vida, estar vivo; literalmente "gracias a quien vivimos".

20 Las cursivas son mías. levantado, con alguna insignia en la mano"21 (Cervantes de Salazar, 1971: vol. I, 134).

Es verdad que en los cantares mexicanos se percibe una abrupta inserción de lo divino cristiano en el contexto del canto de guerra. En esa medida, se trata de una de las yuxtaposiciones más bruscas dentro de esa cultura del sincretismo caracterizada por las yuxtaposiciones.

Pero es importante subrayar que las imágenes militares y las expresiones guerreras no eran en absoluto ajenas a la historia cristiana. De hecho, varios aspectos simbólicos de los conventos que se levantaban por toda la Nueva España estaban inspirados en las evocaciones bíblicas de la morada de Dios como una gran fortaleza (Estrada de Gerlero, 2011: 66-68). La evangelización de pueblos enteros en una nueva tierra había hecho brotar en las órdenes religiosas un sentido de urgencia de la conversión y había revivido la vigencia de las cartas de San Pablo que transmitían ese espíritu de la iglesia militante.

Erasmo, cuyas obras habían sido esenciales en la formación humanista de los franciscanos y otros religiosos, utiliza constantemente las metáforas militares para explicar la acción de los cristianos. "Toda la vida de los mortales no es aquí sino una perpetua guerra" (Erasmo, 1932: 111), "ni un solo momento nos cumple dejar las armas. Siempre es necesario estar en el campo, y aun a punto de guerra [...]" (Erasmo, 1932: 126).

Erasmo piensa en los cristianos como una milicia empuñando las armas, y se refiere a San Pablo como un "capitán" "diestro en ellas" (Erasmo, 1932: 145). Habla de las armas de los guerreros cristianos y menciona el "escudo de la fe viva" (Erasmo, 1932: 146).

En ese enorme esfuerzo de incorporación y de analogía, de comunicación entre las tradiciones indígena y cristiana, los frailes buscaron también una ruta para el militarismo indígena.

Y ésta podía encontrarse en las fuentes de la tradición cristiana pero muy especialmente en el pensamiento de San Pablo, quien, dirigiéndose a los efesios, escribía:

21 Las cursivas son mías. 
"vestíos de toda la armadura de Dios [...] tomad [...] la armadura de Dios [...] Embrazad en todo momento el escudo de la fe, ${ }^{22}$ con que podáis hacer inútiles los encendidos dardos del maligno" (Efesios, VI: 11-17).

\section{Epílogo}

El despliegue espectacular de flores y plumas era parte fundamental de la religiosidad indígena, y a los frailes les pareció correcto aprovecharlo para dar convicción y sustento a la práctica de la nueva religión. Era la cruz cristiana, después de todo, la que emergía entre los estandartes de plumas. Y quienes bailaban incesantemente en las fiestas religiosas, con disfraces e insignias, lo hacían para celebrar a Cristo, para proclamar la idea cristiana de Salvación y vida eterna, para venerar a los santos en sus fiestas.

Los ornamentos y las figuras indígenas eran compatibles con los objetos y las prácticas de la liturgia cristiana.

Anteriormente hemos visto el sentido simbólico de la palia de plumaria y su relación con los sacramentos y con la eucaristía en especial. Una composición pictográfica indígena, realizada con la técnica del mosaico de plumaria, transmitía un mensaje simbólico cristiano a un objeto que tenía un muy preciso uso litúrgico. $\mathrm{Y}$, sin embargo, es verdad que el objeto remite inmediatamente a la imagen de un escudo: era idéntico a los escudos que los indios empuñaban en las fiestas. Era un pequeño escudo, no un escudo para el cuerpo de un joven, de un guerrero, pero es posible que no pasara desapercibido su aspecto de escudo. También ese concepto era compatible con la función de la palia: escudo de fe viva, escudo que hace inútiles los dardos del maligno.

22 Las cursivas son mías.

\section{Fuentes consultadas}

Anders, Ferdinand (1970), "Las artes menores", Artes de México. Arte Plumario y de Mosaico, XVII(137), México, Artes de México y el mundo, pp. 4-45.

Biblia pauperum (1987), ed. Avril Henry, Ithaca, New York, Cornell University Press.

Boone, Elizabeth Hill (1983), The Codex Magliabechiano and the Lost Prototype of the Magliabechiano Group, 2 vols., Berkeley, University of California Press.

Cantares mexicanos (2011), edición de Miguel León-Portilla, 3 vols., México, Universidad Nacional Autónoma de México-Instituto de Investigaciones Históricas.

Cervantes de Salazar, Francisco (1971), Crónica de la Nueva España, 2 vols., Madrid, Ediciones Atlas, Biblioteca de Autores Españoles, tomo 244.

Códice Borgia (1963), 3 vols., México, Fondo de Cultura Económica.

Códice de Huejotzingo (1531), Biblioteca Digital Mundial, <https://www.wdl.org/ es/item/2657/>, diciembre de 2020.

Códice de Tepetlaóztoc (Códice Kingsborough) Estado de México (1994), ed. facsimilar, estudio de Perla Valle, 2 vols, Toluca, El Colegio Mexiquense, A.C.

Durán, Diego (1967), Historia de las Indias de Nueva España e Islas de Tierra Firme, ed. Ángel María Garibay, México, Editorial Porrúa.

Erasmo (1932), El enquiridion o manual del caballero cristiano, ed. Dámaso Alonso, Madrid, S. Aguirre Impresor.

Escalante Gonzalbo, Pablo (2012), "El término 'sincretismo' y el estudio del arte novohispano del siglo XVI", en Patricia Díaz Cayeros, Montserrat Galí Boadella y Peter Krieger (eds.), Nombrar y explicar. Los conceptos en el estudio del arte hispanoamericano, México, Universidad Nacional Autónoma de Méxi- 
co-Instituto de Investigaciones Estéticas, pp. 305-320.

Escalante Gonzalbo, Pablo (2010), Los códices mesoamericanos antes y después de la conquista española. Historia de un lenguaje pictográfico, México, Fondo de Cultura Económica.

Escalante Gonzalbo, Pablo (2006), "Fulgor y muerte de Juan Gerson o las oscilaciones de los pintores de Tecamachalco", en Alberto Dallal (ed.), El proceso creativo. XXVI Coloquio Internacional de Historia del Arte, México, Universidad Nacional Autónoma de México-Instituto de Investigaciones Estéticas, pp. 325-342.

Escalante Gonzalbo, Pablo (2005), "El término 'sincretismo' y el estudio del arte novohispano del siglo XVI", ponencia presentada en el coloquio Nombrar y explicar. La terminología en el estudio del arte ibérico y latinoamericano, 24 de febrero, Instituto de Ciencias Sociales y Humanidades de la Benemérita Universidad Autónoma de Puebla/ UNAM-Instituto de Investigaciones Estéticas, Puebla.

Estrada de Gerlero, Elena Isabel (2011), Muros, sargas y papeles. Imagen de lo sagrado y lo profano en el arte novohispano del siglo XVI, México, Universidad Nacional Autónoma de México-Instituto de Investigaciones Estéticas.

Estrada de Gerlero, Elena Isabel (2005). Comunicación personal.

Filloy Nadal, Laura, Solís Olguín, Felipe y Navarijo Ornelas, María de Lourdes (2007), "Un excepcional mosaico de plumaria azteca: El tapacáliz del Museo Nacional de Antropología", Estudios de Cultura Náhuatl, vol. 38, México, Universidad Nacional Autónoma de México, pp. 85-100.

García Barrios, Ana y Parada López de Corselas, Manuel (2014), "La cruz mexicana del siglo XVI de la Catedral de Palencia (España): La visión indígena del Gólgota como la montaña sagrada",
Anales del Instituto de Investigaciones Estéticas, 36 (105), México, Universidad Nacional Autónoma de México, pp. 127-184.

García Granados, Rafael (1939), "Mexican Feather Mosaics", Mexican Art and Life, núm. 5, enero, México, Departamento Autónomo de Prensa y Publicidad, pp. 1-4.

García Icazbalceta, Joaquín(1981), Bibliografía mexicana del siglo XVI, Catálogo razonado de libros impresos en México de 1539 a 1600. Con biografías de autores y otras ilustraciones, México, Fondo de Cultura Económica.

Horcasitas, Fernando (1974), El teatro náhuatl. Épocas novohispana y moderna, México, Universidad Nacional Autónoma de México-Instituto de Investigaciones Históricas.

INAH (Instituto Nacional de Antrolología e Historia) (2014), Códice Mendoza [Edición digital], Interpretación del Códice Mendoza a partir del libro Essential Codex Mendoza 1992. The Regents of The University California Press, <https://bit. ly/3qyPP6C>, diciembre de 2020.

Lacadena, Alfonso (2006), "Escritura jeroglífica náhuatl: propuestas de análisis, sistematización y desciframiento", Notas de trabajo, Universidad Nacional Autónoma de México-Instituto de Investigaciones Estéticas-Instituto de Investigaciones Filológicas del Centro de Estudios Mayas, 2 a 4 de mayo.

Liturgia papal, El manual de liturgia de Liturgia papal.org, <https://bit.ly/3bo2bbl>, diciembre de 2020.

Martimort, A. Georges (1987), La Iglesia en oración. Introducción a la liturgia, Barcelona, Editorial Herder.

Martínez M., Juan José (pbro.), (s.f.), "Los sacramentos de la iniciación cristiana. Origen e historia", ponencia en el XXXIII Encuentro Nacional de Comisiones Provinciales y Diocesanas de Pastoral Litúrgica, <https://bit. Iy/2ZxIF6N>, 10 de diciembre de 2020. 
Motolinia, fray Toribio de Benavente o (1971), Memoriales o Libro de las Cosas de la Nueva España y de los naturales de ella, ed. Edmundo O'Gorman, México, Universidad Nacional Autónoma de México-Instituto de Investigaciones Históricas.

Nicholson, Henry B. y Quiñones Keber, Eloise (1983), Art of the Aztec Mexico. Treasures of Tenochtitlan, Washington, D. C., National Gallery of Art.

Noguez, Xavier (2016), "Las joyas de Martín Océlotl", Arqueología Mexicana, 24 (142), noviembre-diciembre, México, Editorial Raíces, pp. 12-13.

Nowotny, Karl A. (1961) "Americana”, Archiv für Völkerkunde, Bd. XVI. Vienna.

Psalmodia Christiana (1993), ed. Arthur J. O. Anderson, Salt Lake, University of Utah Press.

Pueblos Originarios, Textos y Documentos, Manuscrito Tovar, <https://bit.ly/3bnKYyP $>$, diciembre de 2020.

Russo, Alessandra (2014), The Untraslatable Image. A Mestizo History of the Arts in New Spain, 1500-1600, Austin, University of Texas Press.

Sahaghún, fray Bernardino de (1993), Psalmodia Christiana, traducción y estudio de Arthur J. Anderson, Salt Lake, Utah, University of Utah Press.

Sahagún, fray Bernardino de (1979), Historia general de las cosas de la Nueva España, ed. facsimilar, 3 vols, México, Secretaría de Gobernación.

Torres, Agathe (2020), "Xicalcoliuhqui chimalli, Feather Shield. Aztec Shields at the Landesmuseum Württemberg", Tribal Art Magazine, núm. 95, marzo, Bélgica, pp. 102-107, <https://bit.ly/3ufztSK>, diciembre de 2020.

Recibido: 4 de diciembre de 2020. Reenviado: 11 de enero de 2021. Aceptado: 26 de enero de 2021.

\section{Pablo Escalante Gonzalbo}

Doctor en Historia por la Universidad Nacional Autónoma de México (UNAM), investigador del Instituto de Investigaciones Estéticas y profesor de la Facultad de Filosofía y Letras de la UNAM. Miembro del Sistema Nacional de Investigadores, nivel III. Sus líneas de investigación son: Arte cristiano-indígena de la Nueva España, arte y liturgia en los pueblos de indios, transformación colonial de los códices, cultura popular y vida cotidiana. Entre sus publicaciones destacan, como autor: "El término 'sincretismo' $y$ el estudio del arte novohispano del siglo XVI", en Patricia Díaz Cayeros, Montserrat Galí Boadella y Peter Krieger, Nombrar y explicar. La terminología en el estudio del arte ibérico y latinoamericano, México, Universidad Nacional Autónoma de México/Instituto de Investigaciones Estéticas, pp. 305320 (2012); Los códices mesoamericanos antes y después de la Conquista. Historia de un lenguaje pictográfico, México, Fondo de Cultura Económica, (2010); El arte cristiano-indígena del siglo XVI novohispano y sus modelos europeos, México, Centro de Investigación y Docencia en Humanidades del Estado de Morelos, (2008); "Fulgor y muerte de Juan Gerson o las oscilaciones de los pintores de Tecamachalco", en XXVI Coloquio Internacional de Historia del Arte. El proceso creativo, México, Universidad Nacional Autónoma de México-Instituto de Investigaciones Estéticas pp. 325-342 (2006); "Cristo, su sangre y los indios. Exploraciones iconográficas sobre el arte mexicano del siglo XVI", en Helga von Kügelgen (ed.), Herencias indígenas, tradiciones europeas y la mirada europea, Fráncfort del Meno, Vervuert Iberoamericana, pp. 71-93 (2002). 
